\title{
Trypanosoma cruzi infection induces up-regulation of cardiac muscarinic acetylcholine receptors in vivo and in vitro
}

\author{
K. Peraza-Cruces ${ }^{1}$, L. Gutiérrez-Guédez ${ }^{1}$, D. Castañeda Perozo ${ }^{1}$, C.R. Lankford ${ }^{1}$, \\ C. Rodríguez-Bonfante ${ }^{2}$ and R. Bonfante-Cabarcas ${ }^{1}$ \\ 1 Unidad de Bioquímica, ${ }^{2}$ Unidad de Parasitología, Centro de Pesquisas Biomédicas, Decanato de \\ Medicina, Universidad Centro Occidental "Lisandro Alvarado", Barquisimeto, Venezuela
}

Correspondence to: R. Bonfante-Cabarcas, Unidad de Bioquímica, Decanato de Medicina, Universidad Centro Occidental "Lisandro Alvarado", Av. Libertador con Av. Andrés Bello, Casilla Postal 3001, Barquisimeto, Lara, Venezuela

Fax: +58-251-259-1950. E-mail: rcabarca@ucla.edu.ve

The pathogenesis of chagasic cardiomyopathy is not completely understood, but it has been correlated with parasympathetic denervation (neurogenic theory) and inflammatory activity (immunogenic theory) that could affect heart muscarinic acetylcholine receptor (mAChR) expression. In order to further understand whether neurogenic and/or immunogenic alterations are related to changes in mAChR expression, we studied two models of Trypanosoma cruzi infection: 1) in 3-week-old male Sprague Dawley rats chronically infected with $T$. cruzi and 2) isolated primary cardiomyocytes co-cultured with $T$. cruzi and peripheral blood mononuclear cells (PBMC). Using $\left[{ }^{3} \mathrm{H}\right]$-quinuclidinylbenzilate $\left(\left[{ }^{3} \mathrm{H}\right]-\mathrm{QNB}\right)$ binding assays, we evaluated mAChR expression in homogenates from selected cardiac regions, PBMC, and cultured cardiomyocytes. We also determined in vitro protein expression and pro-inflammatory cytokine expression in serum and cell culture medium by ELISA. Our results showed that: 1) mAChR were significantly $(P<0.05)$ up-regulated in right ventricular myocardium (means $\pm S E M$; control: $58.69 \pm 5.54, N=29$; Chagas: $72.29 \pm 5.79 \mathrm{fmol} / \mathrm{mg}, \mathrm{N}=34$ ) and PBMC (control: $12.88 \pm 2.45, \mathrm{~N}=18$; Chagas: $20.22 \pm 1.82 \mathrm{fmol} / \mathrm{mg}, \mathrm{N}=19$ ), as well as in cardiomyocyte transmembranes cultured with either PBMC/T. cruzi co-cultures (control: $24.33 \pm 3.83$; Chagas: $43.62 \pm$ $5.08 \mathrm{fmol} / \mathrm{mg}, \mathrm{N}=7$ for both) or their conditioned medium (control: $37.84 \pm 3.84, \mathrm{~N}=4$; Chagas: $54.38 \pm 6.28 \mathrm{fmol} / \mathrm{mg}, \mathrm{N}=20$ ); 2) $\left[{ }^{3} \mathrm{H}\right]$-leucine uptake was increased in cardiomyocytes co-cultured with PBMC/T. cruzi-conditioned medium (Chagas: 21,030 \pm 2321 ; control $10,940 \pm 2385 \mathrm{dpm}, \mathrm{N}=7$ for both; $\mathrm{P}<0.05$ ); 3) plasma IL-6 was increased in chagasic rats, IL-1 $\beta$ was increased in both plasma of chagasic rats and in the culture medium, and TNF- $\alpha$ level was decreased in the culture medium. In conclusion, our results suggest that cytokines are involved in the up-regulation of $\mathrm{mAChR}$ in chronic Chagas disease.

Key words: Chagas disease; Muscarinic acetylcholine receptor; Super-sensitivity; Trypanosoma cruzi; Immunogenic theory; Neurogenic theory

The current address of C.R. Lankford is Division of Monoclonal Antibodies, CDER, U.S. Food and Drug Administration, HFD-123 Bethesda, MD, USA.

Research supported by the National Grants for Science and Technology (Fonacit, Caracas, Venezuela, \#S1-2001001134) and the Scientific, Humanistic, and Technology Developing Council (CDCHT-UCLA, Barquisimeto, Venezuela, \#021-ME-2002 and \#006-ME-2008).

Received October 18, 2007. Accepted August 27, 2008 


\section{Introduction}

Chagas disease is caused by the parasitic protozoan Trypanosoma cruzi, which is transmitted to humans by various species of the bloodsucking insects of the Reduvidae family. Chagas disease is endemic in 21 countries of the Americas and currently there are more than 17 million infected people with 100 million more expected to become infected in the next decade. It is estimated that 1 million new cases are developed per year with 45,000 deaths per year due to advanced disease (1).

In Venezuela, Chagas disease is a public health problem, affecting mainly people living in rural areas under poor sanitary conditions (2). The heart is one of the organs most frequently affected in Chagas disease; 25 to $30 \%$ of the infected cases develop chagasic myocarditis that, if left untreated, leads to heart failure and sudden death (3). Chagasic myocarditis is characterized by dilated myocardiopathy and subsequent alterations of cardiac functions. At the tissue level, it is characterized by myocardial remodeling and associated mononuclear cell infiltration (3). It is intriguing, however, that there is no clear correlation between the presence of $T$. cruzi in the cardiac tissue and the development of chagasic myocardiopathy (4).

The origin of chagasic myocardiopathy has been addressed by two theories: the neurogenic theory postulates that myocardiopathy emerges as the result of an autonomic unbalance. In this scenario, the sympathetic activity predominance is a direct consequence of the loss of parasympathetic input, due to selective and irreversible destruction of the postganglionic vagal neurons, a phenomenon that occurs during the acute phase of infection $(5,6)$. The immunogenic theory postulates that the onset of chagasic myocardiopathy is the direct consequence of an inflammatory response. The myocardial inflammatory infiltrate is the source of a variety of immune mediators, such as neutralizing antibodies and pro-inflammatory cytokines. Immunologic insults can modulate cardiac function by causing direct muscle remodeling associated with modulation of the $\beta$-adrenergic receptor-associated adenylylcyclase activity (7-10). Similarities between $T$. cruzi epitopes and human cardiomyocyte receptor epitopes such as $\beta$ adrenergic receptors, $\mathrm{M}_{2}$-subclass muscarinic acetylcholine receptor (mAChR), nicotinic cholinergic receptors, and certain voltage-dependent channels have been described (11-15).

Antibodies directed at $T$. cruzi antigens, especially those of the IgG class, can act as cholinergic mAChR agonists, reducing atrial contractility and triggering classic mAChR signal transduction outcomes (i.e., cGMP stimulation or cAMP inhibition). Atropine neutralizes these effects by direct competition for the mAChR binding sites, while pertussis toxin acts by preventing the inhibition of cAMP (16). It has been reported that serum from chronic chagasic patients with complex cardiac arrhythmias is able to reduce cardiac rate (17) and induce auricular-ventricular conduction blockades, in isolated beating heart preparations, which is partially antagonized by atropine (18). Furthermore, the relationship between the immune system and the muscarinic cholinergic system is suggested by the report that activation of $\mathrm{mAChR}$ expressed on T cell receptor-activated T cells increases the production of IL-2 (19).

The neurogenic theory predicts that the consequences of parasympathetic denervation should be a muscarinic cholinergic receptor population up-regulation; however, according to the immunogenic theory, putative agonistic activity of the autoantibodies should induce mAChR subsensitivity and desensitization (20). Even though there is strong evidence in favor of both neurogenic and immunogenic theories, some investigators have failed to demonstrate mAChR up- or down-regulation. Torres et al. (21) observed that the mAChR function is neither depressed nor enhanced during the acute stage of Chagas disease in rats. Similarly, Tanowitz et al. (22) did not observe changes in the mAChR number or function in the heart of $T$. cruzi-infected mice.

In the present investigation, we analyzed the status of $\mathrm{mAChR}$ in a rat model of chronic Chagas disease. We evaluated 1) mAChR ex vivo expression in heart muscle and in peripheral blood mononuclear cells (PBMC), and 2) serum levels of pro-inflammatory cytokines in infected animals. Also, using primary cardiomyocytes co-cultured with autologous PBMC and T. cruzi we evaluated 1) mAChR expression in vitro, and 2) the levels of pro-inflammatory cytokines in the culture medium.

\section{Material and Methods}

\section{Animal model}

Three-week-old male Sprague Dawley rats, obtained from the Instituto Venezolano de Investigaciones Científicas (IVIC) animal facilities, were divided into experimental ( $N=$ $29)$ and control groups $(N=36)$. The experimental animals were inoculated intradermally with metacyclic trypomastigotes suspended in $0.9 \% \mathrm{NaCl}$, at a dose of 1000 trypomastigotes per gram of body weight. The T. cruzi MHOM/ VE/92/2-92-YBM strain $(23,24)$ used in these experiments was isolated from the dejections of laboratory-infected Rhodnius prolixus. The control animals were inoculated with a suspension of dejections of healthy $R$. prolixus diluted in $0.9 \% \mathrm{NaCl}$ achieving the same concentration as the inoculum of laboratory-infected $R$. prolixus dejections. All animals were tested for parasitemia levels biweekly and 
those animals belonging to experimental group that tested negative were excluded. After 6 months of infection and under general anesthesia (40 $\mathrm{mg} / \mathrm{kg}$ pentobarbital), 8-12 $\mathrm{mL}$ blood was collected from the abdominal aorta of each animal and the heart was removed for dissection of selected regions (i.e., atria, septum, and both ventricles). All animal studies were carried out in conformity with the American Physiological Society Guiding Principles in the Care and Use of Laboratory Animals (25).

\section{Serum and PBMC isolation}

Non-heparinized blood $(4 \mathrm{~mL})$ was allowed to clot at room temperature and the resulting serum was inactivated at $60^{\circ} \mathrm{C}$ for $30 \mathrm{~min}$. For PBMC isolation, $4 \mathrm{~mL}$ heparinized whole blood was diluted $1: 1(\mathrm{v} / \mathrm{v})$ in cold balanced saline solution (BSS: $5 \mu \mathrm{M} \mathrm{CaCl}_{2}, 0.98 \mu \mathrm{M} \mathrm{MgCl}_{2}, 5.4 \mathrm{mM} \mathrm{KCl}$, $14.5 \mathrm{mM}$ Tris buffer, $0.126 \mathrm{M} \mathrm{NaCl}$, and $5.56 \mathrm{mM} \mathrm{D}$ glucose), loaded onto a 4-mL Ficoll-Paque ${ }^{\circledR}$ cushion (Amersham Pharmacia Biotech, UK) and centrifuged at $1000 \mathrm{~g}$ for $1 \mathrm{~h}$ at $5^{\circ} \mathrm{C}$. The PBMC layer (buffy coat) was carefully recovered, diluted in $5 \mathrm{~mL}$ cold BSS, and centrifuged at $1000 \mathrm{~g}$ for $30 \mathrm{~min}$ at $5^{\circ} \mathrm{C}$. The resulting pellet was resuspended in RPMI medium supplemented with $10 \%$ homologous rat serum, $100 \mathrm{IU} / \mathrm{mL}$ penicillin and $0.1 \mathrm{mg} / \mathrm{mL}$ streptomycin. Cell number and viability was determined by Trypan blue exclusion.

\section{Cardiomyocyte cultures}

Hearts were removed from 1-day-old Sprague Dawley rats under general anesthesia (40 mg/kg pentobarbital) and antiseptic conditions. They were rinsed in cold $\mathrm{Ca}^{2+} / \mathrm{Mg}^{2+}$ free Hank's balanced saline solution, minced and dissociated with $1 \mathrm{mg} / \mathrm{mL}$ collagenase (Worthington Biochemical Corporation, USA) at $37^{\circ} \mathrm{C}$ for $40 \mathrm{~min}$. Collagenase activity was terminated by adding fetal bovine serum (FBS; $20 \%$ final concentration). Dissociated cardiomyocytes were seeded at a density of $1.5-2 \times 10^{5}$ cells $/ \mathrm{mL}$ on laminin-coated $35 \times 10 \mathrm{~mm}$ dishes in complete basal medium Eagle (BME; Gibco Invitrogen Corporation, USA) supplemented with 10\% FBS, $100 \mathrm{IU} / \mathrm{mL}$ penicillin, and $0.1 \mathrm{mg} / \mathrm{mL}$ streptomycin, and incubated at $37^{\circ} \mathrm{C}$ in a $5 \% \mathrm{CO}_{2}$ incubator. After $24 \mathrm{~h}$, the culture medium was totally replaced with fresh complete BME and after that only $50 \%$ of the medium was replaced twice a week. Cardiomyocyte cultures were assayed on the 4 th or 7 th days of culture.

Transmembrane cultures of cardiomyocytes and $T$. cruzi/PBMC co-cultures

Parasites $\left(2 \times 10^{5}\right)$ and PBMC $\left(5 \times 10^{5}\right)$ were co-seeded in an upper transmembrane Millicell ${ }^{\circledR}$ chamber (Millipore Corporation, USA) and co-cultured with 4-day-old cardio- myocytes seeded on the bottom of the main chamber. After $48 \mathrm{~h}$, co-culture media were collected and stored at $-70^{\circ} \mathrm{C}$. The cardiomyocyte layer was scraped, homogenized, and stored at $-70^{\circ} \mathrm{C}$ until further use. Protein content was determined using a modification of Lowry's method (26).

\section{Protein synthesis}

[ $\left.{ }^{3} \mathrm{H}\right]$-leucine (5 $\mu \mathrm{Ci}$; Amersham Pharmacia Biotech) was added to 1-week-old cardiomyocyte cultures concomitantly with $10 \mu \mathrm{M}$ cytarabine to inhibit cellular proliferation. After $24-\mathrm{h}$ incubation at $37^{\circ} \mathrm{C}$ in a $5 \% \mathrm{CO}_{2}$ incubator, cells were washed three times with $2 \mathrm{~mL}$ ice-cold BSS. Cell integrity was disrupted by incubating them with $2 \mathrm{~mL}$ $10 \%$ trichloroacetic acid for $10 \mathrm{~min}$ at $4^{\circ} \mathrm{C}$ following the addition of $2 \mathrm{~mL} 100 \%$ methanol. Preparations were allowed to air-dry before adding $1 \mathrm{~mL} 0.3 \mathrm{~N} \mathrm{NaOH}, 1 \%$ SDS solution and further incubated for $30 \mathrm{~min}$. Solubilized cell preparations $(400 \mu \mathrm{L})$ were assessed for $\left[{ }^{3} \mathrm{H}\right]$-leucinedependent radioactivity levels in a liquid scintillation counter (57\% counting efficiency; Wallac 1410, Pharmacia, Inc., Finland). Total protein levels were also determined as indicated above.

\section{Cytokine determination}

IL-6, IL-1 $\beta$, and TNF- $\alpha$ levels were assessed using commercial ELISA kits, following manufacturer instructions (Biosource Europe S.A., Belgium, http://www.biosourcediagnostics.com/catalog/default.asp?categ=50). Intra-assay coefficients of variation were $5.2 \%$ for IL-6, $4.5 \%$ for TNF- $\alpha$ and 2.8 for IL-1 $\beta$. Interassay coefficients of variation were $9 \%$ for TNF- $\alpha, 9.9 \%$ for IL-6, and $4.5 \%$ for IL-1 $\beta$.

\section{$\left[{ }^{3} \mathrm{H}\right]-\mathrm{QNB}$ binding assay}

Receptor density was measured in quadruplicate in homogenates from isolated cardiomyocytes, PBMC, or selected cardiac regions (atrium, septum, right and left ventricles), using saturating concentrations of $\left[{ }^{3} \mathrm{H}\right]-$ quinuclidinylbenzilate $\left(\left[{ }^{3} \mathrm{H}\right]-\mathrm{QNB}\right)$ in equilibrium binding assay conditions according to Perez et al. (27).

\section{Data analysis}

Data are reported as means \pm SEM. Differences between control and experimental subjects were analyzed by the Student $t$-test and $\mathrm{P}<0.05$ was considered to be statistically significant.

\section{Results}

mAChR expression in $T$. cruzi-infected rat cardiomyocytes Using saturating concentrations of $\left[{ }^{3} \mathrm{H}\right]-\mathrm{QNB}(500 \mathrm{pM})$, we determined the number of $\mathrm{mAChR}$ (specific binding: 
moles of bound [ $\left.{ }^{3} \mathrm{H}\right]$-QNB per mg of protein) in atrium, interventricular septum, and ventricle homogenates from both chagasic and control rats, which displayed similar mAChR density (Table 1). However, the mAChR density was $23 \%$ higher in the right ventricle of $T$. cruzi-infected rats $(72.29$ $\pm 5.79 \mathrm{fmol} / \mathrm{mg}$ ) compared with control $(58.69 \pm 5.54 \mathrm{fmol} /$ mg; $\mathrm{P}<0.05 ;$ Table 1).

mAChR expression in cultured cardiomyocytes

Cardiomyocytes co-cultured with chagasic rat PBMC and $T$. cruzitrypomastigotes displayed a significantly higher $(P<0.05) \mathrm{mAChR}$ density $(43.62 \pm 5.08 \mathrm{fmol} / \mathrm{mg} ; \mathrm{N}=7)$ than those cardiomyocytes co-cultured with healthy rat PBMC and T. cruzi trypomastigotes $(24.33 \pm 3.83 \mathrm{fmol} / \mathrm{mg}$; $\mathrm{N}=7$ ) (Table 2). In order to show that these results are due to soluble molecules secreted by the parasites or by the PBMC as a consequence of cell-parasite interactions, we prepared cardiomyocyte cultures using conditioned medium from 2-day-old chagasic or healthy PBMC/T. cruzi cocultures and tested the cardiomyocyte mAChR density. Cardiomyocytes cultured with conditioned medium from chagasic PBMC/T. cruzi showed increased $(P<0.05)$ $\mathrm{mAChR}$ density $(54.38 \pm 6.28 \mathrm{fmol} / \mathrm{mg} ; \mathrm{N}=20)$ compared with the receptor density detected in cardiomyocytes cul-

Table 1. Muscarinic cholinergic receptor density and distribution in healthy and chagasic rat heart regions.

\begin{tabular}{lcccc}
\hline Cardiac region & $\begin{array}{c}\text { Control } \\
\text { (fmol/mg protein) }\end{array}$ & $\mathrm{N}$ & $\begin{array}{c}\text { Chagasic } \\
\text { (fmol/mg protein) }\end{array}$ & $\mathrm{N}$ \\
\hline A & $109.00 \pm 9.97$ & 20 & $112.00 \pm 8.37$ & 28 \\
IVS & $74.74 \pm 4.12$ & 28 & $75.20 \pm 3.76$ & 36 \\
LV & $77.37 \pm 3.47$ & 22 & $76.30 \pm 3.77$ & 26 \\
RV & $58.69 \pm 5.54$ & 29 & $72.29 \pm 5.79^{*}$ & 34 \\
\hline
\end{tabular}

Data are reported as means \pm SEM. A = atrium; IVS = inter-ventricular septum; $L V=$ left ventricle; $R V=$ right ventricle. ${ }^{*} \mathrm{P}<0.05$ compared to control (Student $t$-test).

Table 2. Muscarinic acetylcholine receptor $(m A c h R)$ and protein expression in cardiomyocytes and peripheral blood mononuclear cells (PBMC).

\begin{tabular}{cccccc}
\hline & \multicolumn{2}{c}{ Cardiomyocytes } & & \multicolumn{2}{c}{ PBMC } \\
\cline { 2 - 3 } \cline { 5 - 6 } & Control & Chagas & & Control & Chagas \\
\hline $\begin{array}{c}\mathrm{mAChR} \\
(\mathrm{fmol} / \mathrm{mg})\end{array}$ & $24.33 \pm 3.83$ & $43.62 \pm 5.08^{*}$ & $12.88 \pm 2.45$ & $20.22 \pm 1.82^{*}$ \\
$\begin{array}{c}\text { Protein } \\
(\mathrm{mg} / \mathrm{mL})\end{array}$ & $1.70 \pm 0.09$ & $2.31 \pm 0.20^{*}$ & $3.31 \pm 0.37$ & $2.07 \pm 0.32^{*}$ \\
\hline
\end{tabular}

Data are reported as means \pm SEM. ${ }^{*} \mathrm{P}<0.05$ compared to control (Student $t$-test). tured in conditioned medium derived from non-chagasic PBMC/T. cruzi co-cultures (37.84 $\pm 3.84 \mathrm{fmol} / \mathrm{mg} ; \mathrm{N}=4)$.

Protein expression in cardiomyocytes and PBMC

First, we determined the effect of chagasic or healthy rat serum on the total protein expression in cardiomyocytes, and we observed increased $(P<0.05)$ total protein expression in cardiomyocytes cultured with chagasic rat inactivated serum $(0.92 \pm 0.1 \mathrm{mg} / \mathrm{mL} ; \mathrm{N}=4)$ compared with control cultures $(0.59 \pm 0.08 \mathrm{mg} / \mathrm{mL} ; \mathrm{N}=4)$. We determined the total protein content in cardiomyocytes from transmembrane cultures and we found that cardiomyocytes co-cultured with chagasic rat PBMC/T. cruzi trypomastigotes expressed higher protein levels $(2.31 \pm 0.20$ $\mathrm{mg} /$ plate; $\mathrm{N}=8$ ) compared with the cardiomyocytes cocultured with healthy rat PBMC and $T$. cruzi trypomastigotes $(1.70 \pm 0.09 \mathrm{mg} /$ plate; $\mathrm{N}=6 ; \mathrm{P}<0.05$; Table 2$)$. The protein synthesis rate, measured by $\left[{ }^{3} \mathrm{H}\right]$-leucine uptake, indicated that cardiomyocytes cultured with chagasic-conditioned medium have an elevated protein synthesis rate $(21,030 \pm 2321 \mathrm{dpm} ; \mathrm{N}=7)$ compared with those cardiomyocytes cultured with healthy conditioned medium (10,940 $\pm 2385 \mathrm{dpm} ; \mathrm{N}=7 ; \mathrm{P}<0.05)$.

mAChR density and protein expression in healthy or chagasic rat non-activated PBMC

Total protein levels were significantly different between chagasic PBMC homogenates (2.07 \pm $0.32 \mathrm{mg} / \mathrm{mL} ; \mathrm{N}=7$ ) and control PBMC homogenates $(3.31 \pm 0.37 \mathrm{mg} / \mathrm{mL} ; \mathrm{N}=7 ; \mathrm{P}<0.05$; Table 2). Interestingly, the changes in $m A C h R$ density, as demonstrated by binding assays, did not parallel those changes observed in total protein levels. Chagasic PBMC preparations presented higher $\mathrm{mAChR}$ density $(20.22 \pm 1.82 \mathrm{fmol} / \mathrm{mg}$ protein; $\mathrm{N}$ $=19)$ than the control $(12.88 \pm 2.45 \mathrm{fmol} / \mathrm{mg}$ protein; $\mathrm{N}=18 ; \mathrm{P}<0.05 ;$ Table 2).

Cytokine levels in chagasic rat plasma and $\mathrm{PBMC} / T$. cruzi co-culture media

IL-6, IL-1 $\beta$ and TNF- $\alpha$ levels in vivo (plasma) and in vitro (PBMC/T. cruzi co-cultures media) were selectively disregulated. As shown in Table 3 , IL-1 $\beta$ serum levels were elevated in chagasic rat plasma compared with control animals (9.15 \pm 2.08 and $3.38 \pm 0.59 \mathrm{pg} / \mathrm{mL}$, respectively; $\mathrm{N}=10$; $\mathrm{P}<0.05)$. IL-1 $\beta$ concentration also appeared elevated in the PBMC- T. cruziculture media (16.54 \pm 4.42 vs $6.76 \pm 1.34 \mathrm{pg} / \mathrm{mL}$, respectively; $\mathrm{N}=10$, $P<0.05)$. IL-6 levels were significantly elevated in chagasic PBMC/T. cruzi co-culture media (21.86 
\pm 3.15 vs $11.64 \pm 1.06 \mathrm{pg} / \mathrm{mL}$, respectively; $\mathrm{N}=10 ; \mathrm{P}<$ 0.05 ), but there were no significant changes in chagasic animal serum in vivo. TNF- $\alpha$ levels were significantly lower in the chagasic PBMC/T. cruzi cultures $(59.39 \pm 3.56$ vs $71.47 \pm 2.77 \mathrm{pg} / \mathrm{mL}$, respectively; $\mathrm{N}=10 ; \mathrm{P}<0.05$ ) but no changes were detected in chagasic animal serum in vivo (Table 3).

\section{Discussion}

The main objective of this study was to determine whether there are changes in the expression of cardiac $\mathrm{mAChR}$ in in vitro and in vivo Chagas disease models. Our results demonstrate the up-regulation of cardiomyocyte muscarinic receptors when these cells were cultured with $\mathrm{PBMC} / T$. cruzi co-cultures. There was also an increase of IL-6 and IL- $1 \beta$ levels in the culture media. However, in our in vivo model, the up-regulation of $\mathrm{mAChR}$ was partially observed only in the right ventricle.

The participation of the muscarinic cholinergic system in the development of chagasic cardiomyopathy is supported by both the neurogenic (6) and the autoimmune theories (11). During the acute phase of Chagas disease, the post-ganglionic vagal neurons of the intra-cardiac plexus are selectively destroyed by either $T$. cruzi cell invasion or by auto-antibodies directed to membrane structures $(5,6)$. The result of either insult should promote the development of functional supersensitivity and/or up-regulation of postsynaptic mAChR in the cardiac muscle, due to a denervation phenomenon. Rocha et al. (28) observed that C57BL/ 6 mice that have been inoculated intraperitoneally with $T$. cruzi trypomastigotes have an increased cardiac muscarinic receptor density 8 months after infection. In our in vivo chagasic rat model, the up-regulation of $\mathrm{mAChR}$ was restricted to the right ventricle from chronic chagasic adult rat heart, which suggests a selective denervation of the right ventricle vagal fibers. However, this explanation is not sufficient to explain the mAChR supersensitivity observed in the cardiomyocytes/PBMC-T. cruzi co-cultures where nervous input is absent.

The possible agonistic activity of some anti-muscarinic and/or anti-nicotinic cholinergic receptor antibodies (11, $12,17)$ could induce receptor functional subsensitivity and down-regulation of the post-synaptic cardiac muscle $\mathrm{mAChR}$, due to an agonist-induced receptor desensitization phenomenon (20); however, this event in cardiac tissues of chagasic animals has not been observed or reported. In the scenario in which both phenomena (vagal denervation and muscarinic receptor modulation by autoantibodies) are supposed to occur simultaneously, each phenomenon could neutralize the other with no overall changes in $\mathrm{mAChR}$ expression. This explains the absence of $\mathrm{mAChR}$ supersensitivity in the other cardiac regions (atrium, septum, and left ventricle) observed in the present investigation in our in vivo rat model. Our observations are consistent with Tanowitz and colleagues (22), who reported no significant changes in the number and kinetics properties ( $\mathrm{Kd}$ and $\mathrm{Bmax}$ ) of the $\mathrm{mAChR}^{22}$ of chagasic mice on the acute phase of the disease. Similarly, Torres et al. (21), working on chagasic Wistar rats in the acute or subacute phase of the disease, also failed to demonstrate any significant cardiac mAChR supersensitivity.

We observed that cardiomyocytes cultured in vitro with PBMC and T. cruzi, in a trans-well system, exhibited enhanced protein synthesis and up-regulation of their $\mathrm{mAChR}$ population. These enhanced parameters could be the result of soluble factors produced by $T$. cruzi-activated PBMC, which are able to modulate $\mathrm{mAChR}$ and other protein expression, as was suggested in the present study. Previously, it has been reported that pro-inflammatory cytokines are able to regulate $\mathrm{mAChR}$ expression, i.e., in human embryonic lung fibroblasts, transforming growth factor $\beta 1$ (TGF- $\beta 1$ ), TNF- $\alpha$, and IL-1 $\beta$ have been associated with $\mathrm{M}_{2}$-subclass $\mathrm{mAChR}$ desensitization (29). Similarly, using HEL 299 cells it has been reported that TNF- $\alpha$ and IL-1 $\beta$ synergistically down-regulate $M_{2}$-subclass $\mathrm{mAChR}$ at the protein and mRNA levels (30). Moreover, incubation of embryonic chicken heart cells with TGF- $\beta 1$

Table 3. Cytokine levels in plasma and culture medium.

\begin{tabular}{|c|c|c|c|c|c|c|}
\hline \multirow[t]{2}{*}{ Group } & \multicolumn{2}{|c|}{ IL-6 (pg/mL) } & \multicolumn{2}{|c|}{$\mathrm{IL}-1 \beta(\mathrm{pg} / \mathrm{mL})$} & \multicolumn{2}{|c|}{ TNF- $\alpha(p g / m L)$} \\
\hline & Plasma & Culture medium & Plasma & Culture medium & Plasma & Culture medium \\
\hline Control & $11.43 \pm 0.98$ & $11.64 \pm 1.06$ & $3.38 \pm 0.59$ & $6.76 \pm 1.34$ & $78.05 \pm 3.34$ & $71.47 \pm 2.77^{*}$ \\
\hline Chagas & $10.26 \pm 2.95$ & $21.86 \pm 3.15^{\star}$ & $9.15 \pm 2.08^{*}$ & $16.54 \pm 4.42^{*}$ & $68.26 \pm 5.57$ & $59.39 \pm 3.56$ \\
\hline
\end{tabular}

Data are reported as means \pm SEM for $N=10$. Culture medium was taken from transmembrane cultures of cardiomyocytes and peripheral blood mononuclear cell/Trypanosoma cruzi co-cultures. ${ }^{*} \mathrm{P}<0.05$ compared to control (Student $t$-test). 
resulted in a concentration- and time-dependent downregulation of the $\mathrm{mAChR}$ transcriptional and translational products, explaining the observed refractory response to carbachol-mediated inhibition of adenylylcyclase activity (31). Also, up-regulation of the $\mathrm{M}_{3}$-subclass $\mathrm{mAChR}$ and CCK-A receptor expression, concomitantly with the elevation of plasma IL-6 levels, was described in a bile-pancreatic juice exclusion from constriction-induced acute pancreatitis in rats (32). Our finding that up-regulation of the cardiac mAChR population could be the consequence of increased local levels of pro-inflammatory cytokines such as IL-6 is consistent with these observations.

Our results demonstrated a significant up-regulation on the right ventricle $\mathrm{mAChR}$ population, suggesting that mAChR supersensitivity is a response to cytokines released by inflammatory cells involved at the myocarditis sites. This idea is supported by our in vitro model of cardiomyocytes trans-well cultured with PBMC-T. cruzicocultures. In this in vitro system the up-regulation of the muscarinic receptors was parallel to high IL-6 and IL-1 $\beta$, but low TNF- $\alpha$ levels detected in the culture-conditioned media, suggesting a modulator effect of these cytokines on the cardiac tissue muscarinic receptor population.

The importance of the integrity of the cholinergic system in the development of Chagas disease myocardiopathy is still controversial. The development of alterations in $\mathrm{mAChR}$ expression and/or function and their role in the pathogenesis of the chagasic cardiac dysfunction could be related to the presence of circulating antibodies against these receptors. It has been reported that patients in the early stages of Chagas disease have circulating autoantibodies to the muscarinic receptors, associated with abnormal modulation of vagal activity (33). Furthermore, serum from chagasic patients is reported to have a muscarinic agonistic activity, evoking strong ventricular re-polarization rhythm disorders (34). Administration of the antiparasitic drug benznidazole during the chronic phase of Chagas infection prevents the development of a more severe form of chronic cardiomyopathy. The amelioration of the cardiac pathology occurs concomitantly with a decrease in the levels of antibodies to the cardiac $\mathrm{M}_{2}$-musca- rinic receptors (35). Likewise, heart dysfunction is prevented in mice infected with Tulahuen $T$. cruzi trypomastigotes if they are treated with an $\mathrm{M}_{2} \mathrm{mAChR}$ immunogenic peptide (36). However, there is no clear correlation between the detectable auto-antibody levels and the clinical parameters of ventricular dysfunction (37).

Mononuclear cell-derived cytokines have also been involved in the development of cardiac tissue remodeling and heart failure $(7,8)$. Studies on the participation of cytokines in Chagas disease evolution suggest that while IL-2 and IFN- $\gamma$ have protective effects during the acute phase of the disease by decreasing the parasite load, TNF- $\alpha$ and IL-10 are associated with an exacerbation of the cardiac damage (38). Studies conducted on Chagas disease patients revealed a correlation between increased serum levels of TNF- $\alpha$ (39) or IL-6 (40) with progression of the disease to more severe clinical stages.

Increased plasma levels of IL-6 must be a consequence of increased heart inflammatory foci indicative of severe damage of postganglionic vagal neurons, which allows adrenergic hyperactivity and muscle mAChR supersensitivity. According to the neurogenic theory, the cardiac autonomic nervous system falls off balance with sustained sympathetic activity, which is the major contributing factor for the progressive deterioration of cardiac function (5).

Our results provide arguments favoring the concept that during Chagas disease evolution, PBMC supply high levels of pro-inflammatory cytokines, such as IL-6 and IL$1 \beta$, which could modulate cardiomyocyte mAChR expression. Increased pro-inflammatory cytokine plasma levels could have origin in diffused heart inflammatory foci, associated or not with postganglionic vagal neuron damage and thus, adrenergic hyperactivity and muscle mAChR supersensitivity.

\section{Acknowledgments}

We express our gratefulness to TSU Carmen Alvarez for her excellent technical assistance.

\section{References}

1. Moncayo A. Chagas disease: current epidemiological trends after the interruption of vectorial and transfusional transmission in the Southern Cone countries. Mem Inst Oswaldo Cruz 2003; 98: 577-591.

2. Añez N, Crisante G, Rojas A, Díaz N, Añez-Rojas N, Carrasco $\mathrm{H}$, et al. La cara oculta de la enfermedad de Chagas en Venezuela. Bol Malariol Salud Ambient 2003;
63: $45-57$.

3. Rassi A, Tranchesi J, Tranchesi B. Doença de Chagas. In: Veronesi A (Editor), Doenças infecciosas parasitarias. 8th edn. Rio de Janeiro: Guanabara Koogan; 1991. p 674-705.

4. Kierszenbaum F. Chagas' disease and the autoimmunity hypothesis. Clin Microbiol Rev 1999; 12: 210-223.

5. Milei J, Stornino R, Jorg M, Chiale P, Schetjman D, Sterin- 
Borda L, et al. Patogenia. In: Storino R, Milei J (Editors), Enfermedad de Chagas. Buenos Aires: Editorial Doyma Argentina SA; 1994. p 103-128.

6. Davila DF, Santiago JJ, Odreman WA. Vagal dysfunction and the pathogenesis of chronic Chagas disease. Int $J$ Cardiol 2005; 100: 337-339.

7. Blum A, Miller H. Role of cytokines in heart failure. Am Heart J 1998; 135: 181-186.

8. Fowler MB, Laser JA, Hopkins GL, Minobe W, Bristow MR. Assessment of the beta-adrenergic receptor pathway in the intact failing human heart: progressive receptor down-regulation and subsensitivity to agonist response. Circulation 1986; 74: 1290-1302.

9. Gulick T, Chung MK, Pieper SJ, Lange LG, Schreiner GF. Interleukin 1 and tumor necrosis factor inhibit cardiac myocyte beta-adrenergic responsiveness. Proc Natl Acad Sci U S A 1989; 86: 6753-6757.

10. Chung MK, Gulick TS, Rotondo RE, Schreiner GF, Lange LG. Mechanism of cytokine inhibition of beta-adrenergic agonist stimulation of cyclic AMP in rat cardiac myocytes. Impairment of signal transduction. Circ Res 1990; 67: 753763.

11. Sterin-Borda L, Borda E. Role of neurotransmitter autoantibodies in the pathogenesis of chagasic peripheral dysautonomia. Ann N Y Acad Sci 2000; 917: 273-280.

12. Wallukat G, Nissen E, Morwinski R, Muller J. Autoantibodies against the beta- and muscarinic receptors in cardiomyopathy. Herz 2000; 25: 261-266.

13. Hernandez CC, Barcellos LC, Gimenez LE, Cabarcas RA, Garcia S, Pedrosa RC, et al. Human chagasic IgGs bind to cardiac muscarinic receptors and impair L-type $\mathrm{Ca}^{2+}$ currents. Cardiovasc Res 2003; 58: 55-65.

14. Pacioretty LM, Barr SC, Han WP, Gilmour RF Jr. Reduction of the transient outward potassium current in a canine model of Chagas' disease. Am J Physiol 1995; 268: H1258H1264.

15. Mukherjee S, Belbin TJ, Spray DC, lacobas DA, Weiss LM, Kitsis RN, et al. Microarray analysis of changes in gene expression in a murine model of chronic chagasic cardiomyopathy. Parasitol Res 2003; 91: 187-196.

16. Goin JC, Perez LC, Borda E, Sterin-Borda L. Modification of cholinergic-mediated cellular transmembrane signals by the interaction of human chagasic IgG with cardiac muscarinic receptors. Neuroimmunomodulation 1994; 1: 284-291.

17. Goin JC, Borda ES, Auger S, Storino R, Sterin-Borda L. Cardiac $M(2)$ muscarinic cholinoceptor activation by human chagasic autoantibodies: association with bradycardia. Heart 1999; 82: 273-278.

18. de Oliveira SF, Pedrosa RC, Nascimento JH, Campos de Carvalho AC, Masuda MO. Sera from chronic chagasic patients with complex cardiac arrhythmias depress electrogenesis and conduction in isolated rabbit hearts. Circulation 1997; 96: 2031-2037.

19. Fujino H, Kitamura Y, Yada T, Uehara T, Nomura Y. Stimulatory roles of muscarinic acetylcholine receptors on $\mathrm{T}$ cell antigen receptor/CD3 complex-mediated interleukin-2 production in human peripheral blood lymphocytes. Mol Pharmacol 1997; 51: 1007-1014.

20. Yamanushi TT, Shui Z, Leach RN, Dobrzynski H, Claydon TW, Boyett MR. Role of internalization of M2 muscarinic receptor via clathrin-coated vesicles in desensitization of the muscarinic $\mathrm{K}^{+}$current in heart. Am J Physiol Heart Circ Physiol 2007; 292: H1737-H1746.

21. Torres A, Davila DF, Gottberg CF, Donis JH, Arata de Bellabarba G, Ramoni-Perazzi P. Heart rate responses to a muscarinic agonist in rats with experimentally induced acute and subacute chagasic myocarditis. Rev Inst Med Trop São Paulo 2000; 42: 219-224.

22. Tanowitz HB, Davies $P$, Wittner M. Alterations in acetylcholine receptors in experimental Chagas' disease. $J$ Infect Dis 1983; 147: 460-466.

23. Matousek de Abel de la Cruz AJ, Burguera JL, Burguera M, Anez N. Changes in the total content of iron, copper, and zinc in serum, heart, liver, spleen, and skeletal muscle tissues of rats infected with Trypanosoma cruzi. Biol Trace Elem Res 1993; 37: 51-70.

24. Labrador Hernández MJ, Suárez Graterol OJ, RodríguezBonfante C, Bonfante-Cabarcas RA. Electrocardiographic study of the cholinergic system in cyclophosphamide induced-Chagas dilated myocardiopathy in Trypanosoma cruzi infected rats. Invest Clin 2008; 49: 207-224.

25. Institute for Laboratory Animal Research (ILAR). Guide for the care and use of laboratory animals. Washington: National Academy Press; 1996.

26. Waterborg JH, Matthews HR. The Lowry method for protein quantitation. Methods Mol Biol 1994; 32: 1-4.

27. Perez CC, Tobar ID, Jimenez E, Castaneda D, Rivero MB, Concepcion JL, et al. Kinetic and molecular evidences that human cardiac muscle express non-M2 muscarinic receptor subtypes that are able to interact themselves. Pharmacol Res 2006; 54: 345-355.

28. Rocha NN, Garcia S, Gimenez LE, Hernandez CC, Senra JF, Lima RS, et al. Characterization of cardiopulmonary function and cardiac muscarinic and adrenergic receptor density adaptation in C57BL/6 mice with chronic Trypanosoma cruzi infection. Parasitology 2006; 133: 729-737.

29. Barnes PJ, Haddad EB, Rousell J. Regulation of muscarinic M2 receptors. Life Sci 1997; 60: 1015-1021.

30. Haddad EB, Rousell J, Lindsay MA, Barnes PJ. Synergy between tumor necrosis factor alpha and interleukin 1beta in inducing transcriptional down-regulation of muscarinic M2 receptor gene expression. Involvement of protein kinase A and ceramide pathways. J Biol Chem 1996; 271: 32586-32592.

31. Jackson DA, Nathanson NM. Regulation of expression and function of $\mathrm{m} 2$ and $\mathrm{m} 4$ muscarinic receptors in cultured embryonic chick heart cells by transforming growth factorbeta 1. Biochem Pharmacol 1997; 54: 525-527.

32. Samuel I, Zaheer A, Zaheer S, Fisher RA. Bile-pancreatic juice exclusion increases cholinergic M3 and CCK-A receptor expression and interleukin-6 production in ligation-induced acute pancreatitis. Am J Surg 2004; 188: 511-515.

33. Ribeiro AL, Gimenez LE, Hernandez CC, de Carvalho AC, Teixeira MM, Guedes VC, et al. Early occurrence of antimuscarinic autoantibodies and abnormal vagal modulation in Chagas disease. Int J Cardiol 2007; 117: 59-63.

34. Medei E, Pedrosa RC, Benchimol Barbosa PR, Costa PC, Hernandez CC, Chaves EA, et al. Human antibodies with muscarinic activity modulate ventricular repolarization: basis for electrical disturbance. Int J Cardiol 2007; 115: 373-380.

35. Garcia S, Ramos CO, Senra JF, Vilas-Boas F, Rodrigues MM, Campos-de-Carvalho AC, et al. Treatment with benz- 
nidazole during the chronic phase of experimental Chagas' disease decreases cardiac alterations. Antimicrob Agents Chemother 2005; 49: 1521-1528.

36. Sterin-Borda L, Joensen L, Bayo-Hanza C, Esteva M, Borda E. Therapeutic use of muscarinic acetylcholine receptor peptide to prevent mice chagasic cardiac dysfunction. $J \mathrm{Mol}$ Cell Cardiol 2002; 34: 1645-1654

37. Talvani A, Rocha MO, Ribeiro AL, Borda E, Sterin-Borda L, Teixeira MM. Levels of anti-M2 and anti-beta1 autoantibodies do not correlate with the degree of heart dysfunction in Chagas' heart disease. Microbes Infect 2006; 8: 2459-2464.

38. Dutra WO, Gollob KJ, Pinto-Dias JC, Gazzinelli G, CorreaOliveira R, Coffman RL, et al. Cytokine mRNA profile of peripheral blood mononuclear cells isolated from individuals with Trypanosoma cruzi chronic infection. Scand J Immunol 1997; 45: 74-80

39. D'Angelo-Mendoza E, Rodriguez-Bonfante C, Camacho I, Martinez J, Perdomo T, Cabrera A, et al. Patients suffering dilated chagasic cardiopathy or non chagasic cardiopathy show increased levels of tumor necrosis factor alpha. Invest Clin 2005; 46: 229-240.

40. López L, Arai K, Jiménez E, Jiménez M, Pascuzzo C, Rodríguez-Bonfante $\mathrm{C}$, et al. Las concentraciones séricas de interleucina 6 y proteína $C$ reactiva se incrementan en la medida en que la enfermedad de Chagas evoluciona hacia el deterioro de la función cardíaca. Rev Esp Cardiol 2006; 59: 50-56. 